\title{
Conversion of Agricultural Land and its Impact on Peasants in Hanoi Suburbs During Rapid Urbanization : A Case Study of Me Tri Commune
}

\author{
NGUYEN Thi Ha Thanh \\ Graduate Student, Global COE-Research Assistant, Kansai University
}

\begin{abstract}
For the past fifteen years, Hanoi, the capital and second largest city of Vietnam, has spatially expanded, and the urban population rate has risen dramatically. The need to convert a great deal of agricultural land into industrial, commercial, and residential land has arisen to meet the challenges of this expansion. It is the aim of this paper to clarify the situation of conversion of agricultural land and its effects on peasants who have lost agricultural land in suburban areas of Hanoi. A bottom-up approach through household interviews was employed to examine the impact of conversion of agricultural land on peasants in a small-scale commune, Me Tri Commune, which is the case study of this research. The paper is composed of three parts. The first section highlights the rapid urbanization and policies of agricultural land recovery, especially compensation for loss of agricultural land, in Hanoi. The second section introduces agricultural land transition, agricultural land recovery and agricultural land compensation in Me Tri Commune from 2000 to 2007. It is acknowledged that the transition of Me Tri Commune from a rural area into an urbanized area at a rapid rate results in a deep transformation in the lifestyles and occupations of the peasants there, which gives rise to a great deal of problems and confusion. Three such problems that arose for peasants in Me Tri Commune during that period as a result of the process of agricultural land conversion included : a transition in labor, a decline in traditional foodstuff production, the use of compensation money, and future risks. Although most of the land that has been converted in Me Tri Commune during this urbanization was agricultural land and many peasants do not need to migrate from their own hometown, the research has clearly demonstrated that the challenges caused by agricultural land conversion in this commune have affected their lives greatly in every aspect.
\end{abstract}

Key words : urbanization, conversion of agricultural land, peasants, Hanoi, Vietnam

\section{Introduction}

By adopting a socialist form of government, Vietnam has experienced processes and features of urbanization, which is unique among the countries of Southeast Asia. From 1954, North Vietnam (which was separated from the South by the 17th parallel) under the Democratic Republic experienced a so-called "freezing [of] urban growth" (Dwyer 1990, 304-306; Thrift and Forbes 1986, 87-97) because of both the Vietnam War and political decisions. The total urban population was estimated to have increased slowly from 4.9\% in 1945 to $9.8 \%$ in 1970 (Nguyen 
1974, 352-357). The impact of this pattern spread toward the South after re-unification of the country in 1975. A migrant influx from cities to rural areas, from plains to mountainous regions, and from the north to the south was expected to distribute urbanization evenly over the country in this period. It was only after enactment of the Dổi Mói (Renovation) Policy from 1986 that the private economy recovered, and the constraints on urbanization in cities were removed. Urbanization in the next period is concentrated on urban growth poles, led by Hanoi in the north and Ho Chi Minh City in the south. These two largest cities of Vietnam accounted for $32.2 \%$ of the total urban population in 2007 (General Statistical Office 2010). It must be remembered that, as in many countries in Southeast Asia, urbanization in Vietnam resulted mainly from accumulation of land and concentration of labor for urban development. The country is now in the stage of "over-urbanization," "hyper-urbanization," or, in other words, "urban hypertrophy" (Evers and Korff 2003, 9; Limi 2005, 88-109). In a country like Vietnam, where $50.2 \%$ percentage of labor force are peasants (in 2007) (General Statistical Office 2010), the problem of "de-agrarianization," which refers to the trend of losing agricultural labor and abandoning (or idling) agricultural land in the urbanization process (Jonathan 2003, 295), is emerging simultaneously with over-urbanization.

Lagging behind developed countries in Southeast Asia, Vietnam exhibited a medium rate of 3.1 $\%$ urbanization in the period $2000-2005$, as well as a low percentage of urban population, at $26.4 \%$ in 2005 (United Nations Population Division 2007; World Bank 2003). In its effort to accelerate urban development, the state has converted a large part of agricultural land into areas for industrial, commercial and residential use. As a result, the construction of industrial, urban zones and infrastructures consumed 366,000 ha of agricultural land, or approximately $4 \%$ of total agricultural land area in the period 2001-2005. Accordantly, more than 2.5 million people (or 627,000 farm households) have been affected (Ministry of Agriculture and Rural Development 2007). In this rural-urban transition, peasants have become the focus of public attention, which is represented by mainstream of news, e-newspapers, broadcast media, and scientific research.

Making Markets Work Better for the Poor (M4P), a large-scale project co-financed by foreign organizations, was implemented in Vietnam during 2004-2007. One result of the project was about "Agricultural Land Conversion : Competing Interests of the Poor," highlighting multidimensional impacts of the conversion of agricultural land for industrial and commercial uses in Vietnam : on one hand it promotes the private sector, but on the other hand, it raises social problems such as displaced households owing to disruption in livelihood, social and cultural dislocation, and food insecurity (Asia Development Bank 2007).

Besides, some research has been conducted on the impact on Hanoi-the capital and second largest city of Vietnam-of land conversion for urbanization. The project "Seeking Synergy between Urban Growth, Horticulture and Environment in Asian Metropolises" (SEARSYN) researched the impact of urbanization on livelihoods of peasants in Gia Lam and Long Bien districts of Hanoi in 2004 through interviews with district and municipal officials (top-down approach). The main problems faced by local residents were loss of agricultural jobs and inability to engage in the industrial sector or to use money appropriately for securing alternative jobs (Nguyen 2005). Two other studies, one by Michael Leaf and another by Vu Hong Phong, explain in detail the consequences of the conversion on peasants. Peasants in Phu Gia village in western Hanoi, as Michael Leaf points out, gained the opportunity to "expand into the production of ornamental trees," for local needs as well as foreign export in the shift toward a 


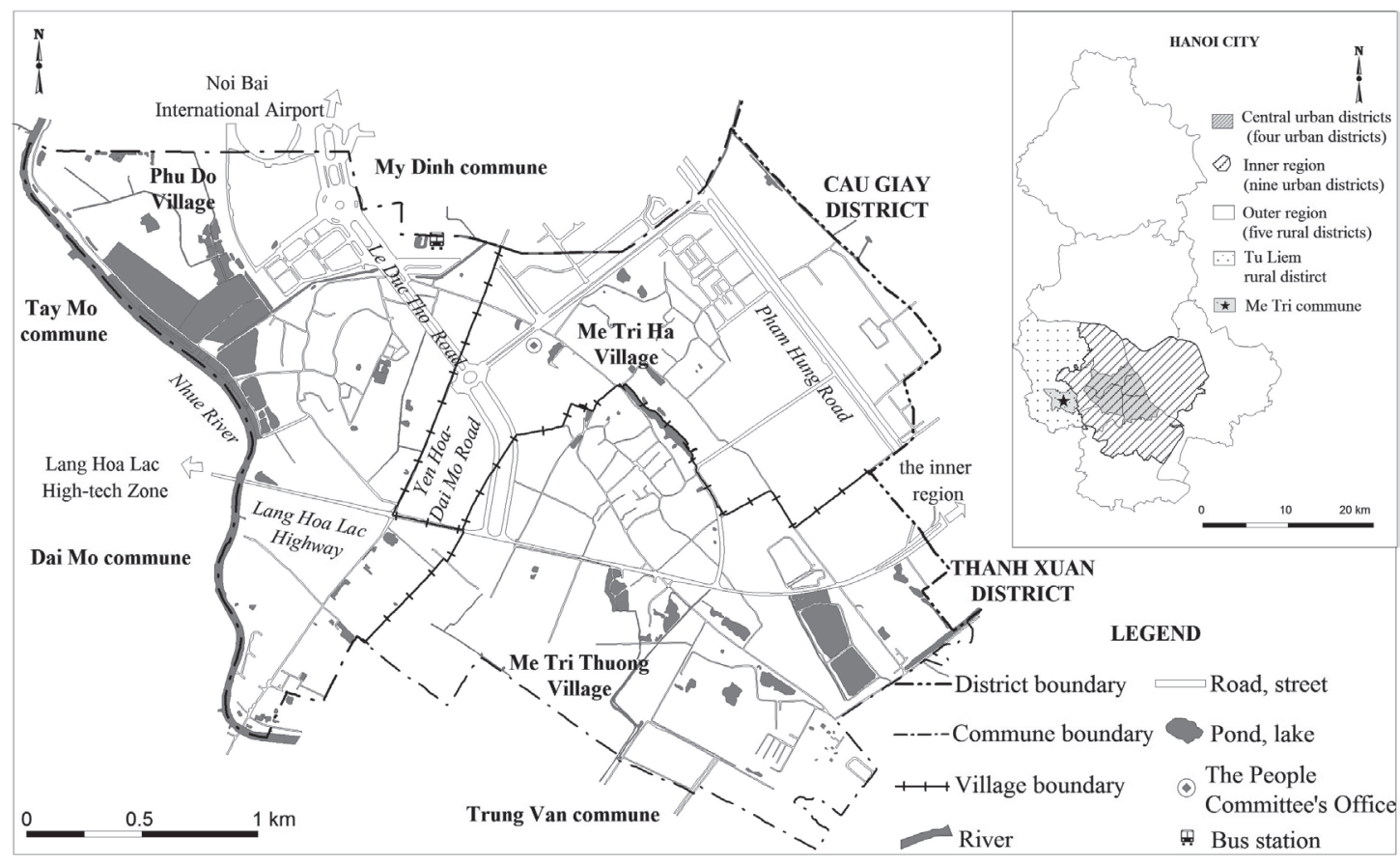

Figure 1. Administrative map of Me Tri commune, 2005.

Base map : the administrative map by Me Tri People's Committee, 2005

market economy (Leaf 2002, 23-31). According to Vu Hong Phong, peasants in a similar situation in Thach Ban commune (an eastern 'ward' of Hanoi from 2004), are able to increase income thanks to the possibility of delivering "safe/clean vegetables" and flowers to the inner region. However, this benefit will soon disappear as the remaining agricultural land in the commune is lost $(\mathrm{Vu} 2006,51-60)$. Concomitantly, there is an increased flow of urban residents and wealthy people to Phu Gia village who create a large gap in living standards with the local peasants. While that, in the case of Thach Ban commune, that is an influx of average laborers from other regions who work in new factories in the commune.

These previous studies clarify the opportunities and the burdens on individuals in urbanized areas through land conversion. Yet there are drawbacks in each of the methodologies employed, whether: it is the top-down approach (the SEARSYN Project), review of general statistics $(\mathrm{Vu}$ Hong Phong, Michael Leaf), or large-scale general surveys of data for the provinces (the M4P Project). Concrete statistics that give strong evidence to support the ideas discussed have been lacking.

To examine the impact of the conversion of agricultural land on peasants, the bottom-up approach through household interviews in a small-scale of commune should be employed. For this purpose, Me Tri commune, located in the Tu Liem suburban district of Hanoi (see Figure 1), was chosen as the key region for this research for three reasons: (1) Here, the rapid urbanization of Hanoi is conspicuous in the emergence of numerous modern and high-rise buildings in place of the rural landscape, yet the main portion of converted land was agricultural land. Therefore, a large number of peasants lost agricultural land, the main object of this study, was numerously counted; (2) Peasants in Me Tri commune also were engaged in traditional 
manual production of bún and cốm, which made them unique compared to peasants in other regions; (3) In relation with the concerns, Me Tri commune has not been scientifically researched yet.

Field work in Me Tri commune was conducted in a total of three times : the first time in July 2006, for nearly two weeks, with a visit to the People's Committee office (a commune's governmental office) to obtain permission for a household survey and to collect basic socioeconomic data and reports. The second time was in February, 2007, for three weeks, to conduct household interviews. The last time was in May, 2007, for nearly two weeks, to conduct further household interviews. The household survey was carried out at about 200 farm households that lost agricultural land but had not yet been displaced from residential land, in three villages of the commune: Me Tri Ha, Me Tri Thuong, and Phu Do. Because of the sensitivity of the interview's contents, some households were hesitant to provide accurate facts, instead giving illogical information. Suspect information was rejected after a preliminary analysis. Finally, 152 survey samples were accurate enough to provide us with clear data.

\section{Urbanaization and Compensation for the Loss of Agricultural Land in Hanoi}

\section{Context of Rapid Urbanization}

In the administrative hierarchy of Vietnam, Hanoi is one of five cities under the direct management of the central government (Hanoi, Ho Chi Minh City, Hai Phong, Da Nang, Can Tho) that represents a nationally strategic position economically, culturally, socially and militarily. Additionally, in terms of the urban hierarchy, Hanoi and Ho Chi Minh cities are considered as special urban entities, which are ahead in every aspect and advance the socioeconomic development of the country (Vietnam Government 2001).

After a long period of constraint on urbanization in the north-at least until 1986-Hanoi was left far behind Ho Chi Minh City. Until 2007, the urban population rate of Hanoi had reached just $65.3 \%$, still far lower than that of Ho Chi Minh City more than ten years earlier, at $74.7 \%$ in 1995 (up to $85.1 \%$ in 2007) (General Statistic Office 2010). Nevertheless, the drastically increased rate of urban population growth in Hanoi within the last fifteen years cannot be ignored.

After enforcement of the Dổi Mói Policy, Hanoi began urbanizing, including the building of several foreign-capitalized hotels, restaurants, souvenir shops, clothing and accessories shops, travel agencies, and 3-5 floored villas (for foreigners to rent) (Noma 1999, 289). Concomitantly, there was a typical disappearance of green space and natural water surface in the four central urban districts (see Figure 1) (Shibayama 2009; Pham and Yamaguchi 2008 ; Ho and Shibayama 2009). As urbanization reached levels of high population density (on average, 31,276 people/ $\mathrm{km}^{2}$ in 2004 (General Statistic Office 2006)), the increasing insufficiency of available land for urban development resulted in the central urban districts spreading to the adjacent rural districts and agricultural surrounding belt. From 1995 till 2007, the inner region of Hanoi witnessed three periods of expansion, 1995 (Vietnam Government 1995), 1996 (Vietnam Government 1996), and 2003 (Vietnam Government 2003), toward the west, southwest, south and slowly to the east. As a result, the increased rates of urban population in Hanoi were typically accelerated in two periods, at $8.3 \%$ in 1996-1997 and $9.0 \%$ in 2002-2003 (General Statistic Office 2010). Highways, roads, industrial zones, supermarkets, privately-owned shops, tall buildings for 
residence, offices, and companies as well as new and modern residential zones, have rapidly displaced the agricultural and rural landscape of the Hanoi suburbs. Many new national buildings have been constructed, concentrated in Hanoi, such as : the My Dinh Complex Sport Center, National Convention Center, etc.

After expansion of the inner region in 1995 through 1996, Me Tri commune became a suburban area. Nevertheless, it was not until 2000 that the social and economic structure of the commune was greatly transformed thanks to several urban construction projects. Me Tri is located at the node of two developing axes (see Figure 1) : Hanoi-Noi Bai International Airport (to the north) and Hanoi-Lang Hoa Lac high-technology zones (to the west), which have experienced more rapid urbanization than that of other suburbs. For this geographical characteristic, Me Tri at the same time plays twofold functions: it serves the demands of population migration from the inner region, as well as supplies land for newly and importantly administrative, cultural and residential buildings. From an agricultural village whose economy was based on rice cultivation and production of two foodstuffs-cốm and bún-the commune has transformed rapidly into a place of national facilities, and a residential zone for students of nearby universities.

\section{Compensation for Loss of Agricultural Land}

Because the government has socialized all land, Vietnam pursues the conversion of agricultural land for urban use by a procedure of agricultural land recovery. In return, compensation for loss of agricultural land is paid to peasants in accordance with the country's land laws. The Land Law 2003 stipulates that the loss of agricultural land should be better compensated with their agricultural land. Nevertheless, in Hanoi, because of its limited agricultural land area, cash compensations have been documented since 2005 (Hanoi People's Committee 2005).

In Me Tri commune, no cases of compensation with agricultural land have been documented for several years (from 1996). Labor transition from the agricultural sector to non-agricultural sectors is a trend that has been made compulsory. In general, after Land Law 1993 was superseded by Land Law 2003, the average compensation price for agricultural land in Hanoi rose discernibly. While the price fluctuated from 9,800 to $19,300 \mathrm{VND} / \mathrm{m}^{210}$ for agricultural land for levels 1 to 4 in accordance with the old land law, it rose dramatically from 54,000 to $108,000 \mathrm{VND} / \mathrm{m}^{2}$ (Hanoi People's Committee 2004) based on the new land law. Additionally, Decree 22/1998/ND-CP of April 24, 1998 stipulated calculations based on a coefficient factor, K, which defines the ratio between the profitability of the value of the land (or land price in the estate market) and a price determined by a provincial people's committee (Ministry of Finance 1998 ). With coefficient $\mathrm{K}$, the nearer to the inner region of cities a commune is, the more compensation money people can receive. In other words, $\mathrm{K}$ determines higher land prices for compensation in suburban regions, where the agricultural land value is actually higher than that of rural areas in the real estate market. Certainly, this change satisfies the peasants in the urban fringes.

Nevertheless, insurmountable problems still exist. Of the many types of land use, agricultural land is valued quite low for compensation. Although for the peasants, agricultural land is an invaluable source of livelihood, in general the compensation price is decided subjectively by the appropriate authorities, with little correspondence or consultation with the displaced peasants (National Economic Research Institute of Vietnam 2006). Also, because of a change in compensation price, there is a gap between the amount of compensation money granted for 
agricultural land recovered earlier and in more recent years. The same problem arose with support money for labor and lifestyle conversion when amounts rose from $9,600 \mathrm{VND} / \mathrm{m}^{2}$ in 1998 (to support the labor transition) to $60,000 \mathrm{VND} / \mathrm{m}^{2}$ in 2003 (of which $25,000 \mathrm{VND} / \mathrm{m}^{2}$ was used to support labor transition, and $35,000 \mathrm{VND} / \mathrm{m}^{2}$ to support livelihood stability) (Hanoi People's Committee 1998 and 2003). Both land compensation and labor support is mostly implemented through compensation in cash.

\section{Conversion of Agricultural Land in the Urbanization of Me Tri Commune}

\section{Conversion of Agricultural Land}

Me Tri commune is located on the western edge of urban Hanoi, about $8.5 \mathrm{~km}$ from the center of the city. The population of the commune has increased from 14,284 people in 2000 to 19,943 people in 2005 (comprising $7.8 \%$ of the total population of Tu Liem rural district). The contemporary landscape of Me Tri commune is a striking combination of rural and urban landscapes, formed by high-rise buildings, and paddy fields and idle land plots located side-byside, with cows lounging here and there on new, wide roads. As a strategic area designated for deconcentrating the congested inner region of Hanoi, Me Tri commune is a new area for the construction of private and governmental offices, branch companies, and modern residential buildings.

Figure 2 demonstrates that the incursion of urbanization in Me Tri commune is from the north and northeast directions. Agricultural land still remains in the west, south, and the center of the commune (a region along the Le Duc Tho Highway-a big new road-still remains agricultural land). The most significant construction works changing not only the landscape but also the living standards of local inhabitants are: the Lang Hoa Lac Highway, the main road connecting inner Hanoi with the outer southwest; the National Convention Center (built in 2004), where the 14th Asia Pacific Economic Conference (APEC) was organized; the My Dinh Complex Sport Center (built between 2000-2002), where the Southeast Asian Games 22nd (SEA Games) were played; the My Dinh-Me Tri urban zone (built in 2002), one of the most modern buildings in Hanoi; Nam Trung Yen resettlement zone (built in 2000) and Me Tri Ha urban zone (constructed in 2002). Through these various projects, the cumulative land area in transition in Me Tri commune increased steadily from $5.8 \%$ to $37.2 \%$, compared with the total land area in the short period from 2000 to 2006 (People's Committee of Me Tri commune 20002006). This rate maintains an upward trend.

Obviously, as an area designated for residential and office zones, Me Tri commune attracts an influx of white-collar workers, middle-and-high class residents, students, and seasonal workers, which is the predominant factor contributing to a high rate of population increase in this commune. The rate reached $6.2 \%$ in the period from 2000 to 2001, and then rose to $7.2 \%$ from 2003 to 2004. Later, it decreased to $5.0 \%$ from 2004 to 2005 (People's Committee of Me Tri commune 2000-2006), but was still higher than that of Hanoi $(2.0 \%)$ and the whole country in general $(1.17 \%)$ in the same period (General Statistical Office 2010).

\section{Agricultural Land Recovery}

In Me Tri commune, 2,174,989.6 $\mathrm{m}^{2}$ of agricultural land has been recovered for thirty-nine urban development projects, accounting for $81.2 \%$ of total recovered land area. In total, the area 


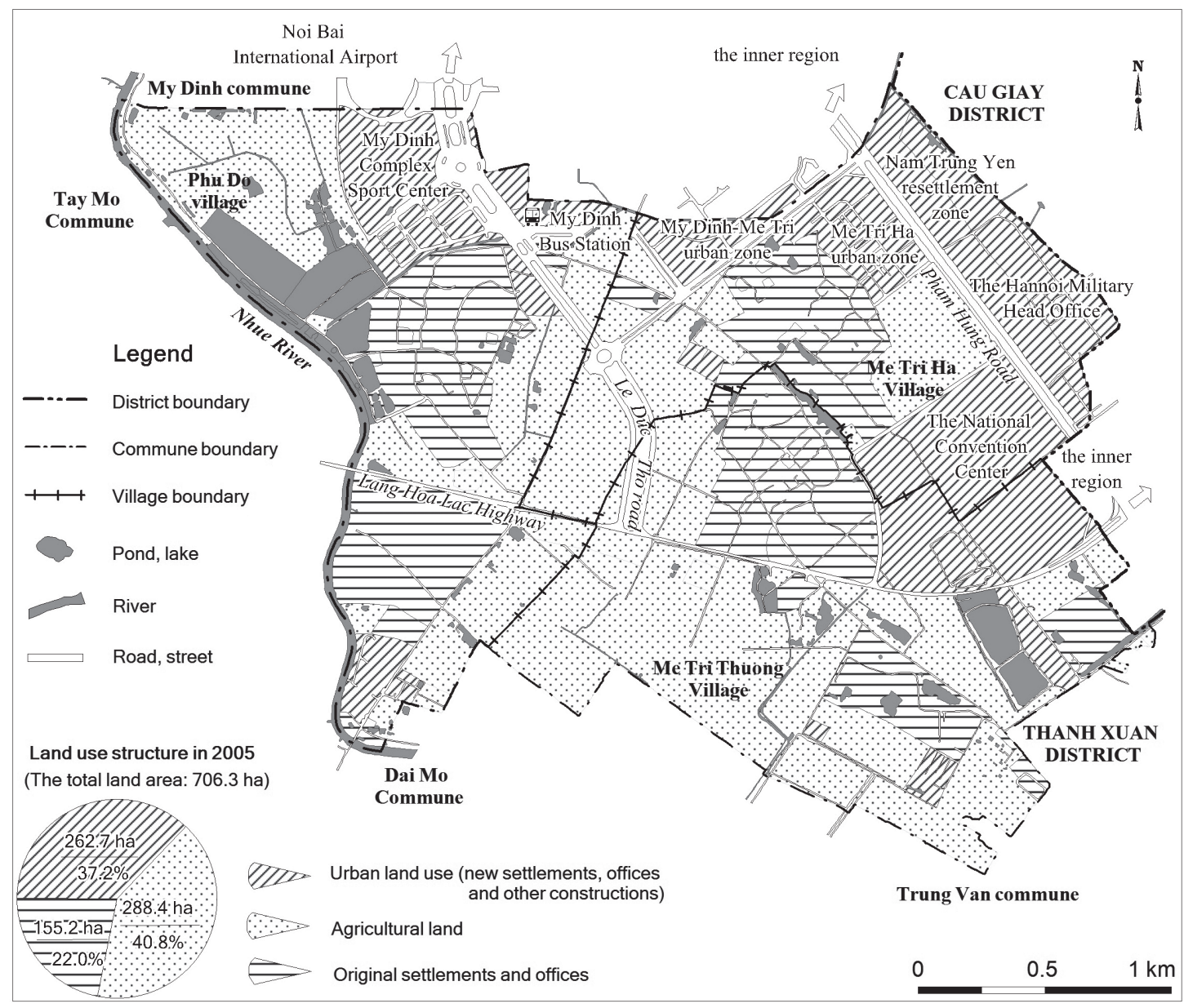

Figure 2. Land use in Me Tri commune in 2005.

Base map: the land use map by Me Tri People's Committee, 2005

of agricultural land was decreased from $60 \%$ to $36 \%$ of the total land area during the period from 2000 to 2006 (People's Committee of Me Tri commune 2000-2006). The agricultural land was typically not recovered all at once, but gradually year by year, making it difficult for peasants to readily cultivate their smaller and smaller plots of land.

According to the survey samples, each household lost $972 \mathrm{~m}^{2}$ of cultivated land on average until 2006, retaining $67.5 \%$ of the land area they used to possess. The amount of land they now hold cannot meet their requirements for either consumption or commercial purposes. Further, the interval from announcement to implementation of agricultural land recovery for each project takes only 3-4 months, too short a time for the peasants to prepare for new lives or search for new occupations.

\section{Agricultural Land Compensation}

In Hanoi, commune levels are categorized by urban degree and socio-economic importance into four ranks: suburban communes, and communes from level 1 to level 3 in descending order. Accordantly, subsequent to the contiguousness with the inner region, Me Tri commune 


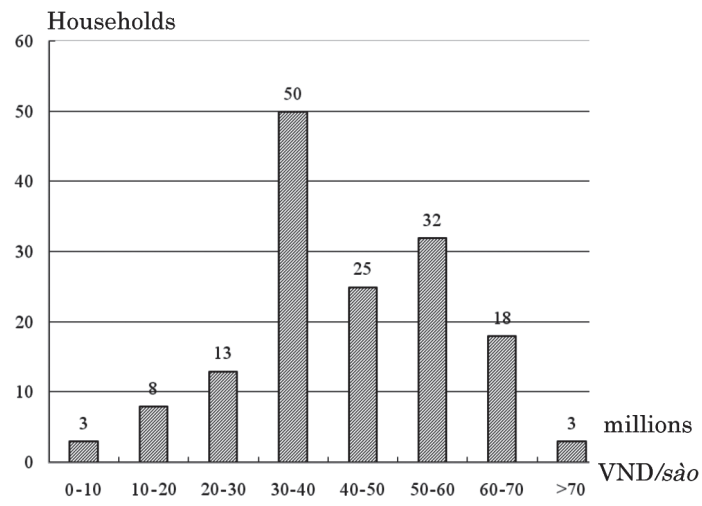

Figure 3. Average compensation money for recovering agricultural land that farm households receive by degree. Data source : original survey data, 2007

was ranked up from commune at level 1 to a suburban commune, through the Appendix I enclosed with Decision 06/1998/QD-UB on April 25, 1998. This turning point raised its K factor (from $K=1.6-1.7$ to $K=2.7$ ), hence steadily increasing the general compensation price for land in Me Tri. Figure 3 is a bar graph showing degrees of compensation money based on our survey samples. It is clear that most households (107 households or $70.4 \%$ of the total sample) received a compensation price of between 30-60 million VND/sào. Another 11 households (7.2 \%), who for the most part returned their agricultural land earlier-from 1996 to 1998-were paid an amount of less than 10 to 20 million VND/sào. The smallest percentage, 3 households ( $2 \%)$, benefited the most from compensation-over 70 million VND/sào-because their land was recovered after 2007. Sometimes, in order to accelerate the progress of a construction project, investors are willing to pay more to peasants who stubbornly refuse to return their land. This, of course, displeases those who transfer their land in time.

\section{Impact of the Conversion of Agricultural Land on the Peasants}

\section{Labor Transition}

After some years of urbanization in Me Tri commune, many peasants no longer want to continue pursuing agricultural activities. The agricultural sector, composed of both crop cultivation and animal husbandry, has been undermined beyond the control of the local government. There were $73.0 \%$ farm households in 152 survey samples that still retained agricultural land, with a total land area of 225 sào $\left(81,000 \mathrm{~m}^{2}\right)$. Of these farm households, only $40.5 \%$ continue to grow rice or vegetables in 87 sào $\left(31,320 \mathrm{~m}^{2}\right)$, while 138 sào, or $61.3 \%$ of the total land area they maintain, is left fallow. Crop cultivation is curtailed by the following three factors: (1) Urban construction has destroyed some of the irrigation system, causing a considerable area of arable land to be abandoned because of an inadequate water supply. (2) The peasants found it impossible to invest continuously or cultivate lucratively in dispersed remaining land parcels. (3) Many peasants intend to engage in new jobs rather than keep waiting for the time when all of their agricultural land is recovered in the rapid process of urbanization. 
The situation for animal husbandry is no better. Space for keeping domestic livestock (chickens, pigs) in many households has been reduced in order to extend a living house : only $25.7 \%$ of the total of interviewed households still rear cattle on a small scale.

In lieu of agricultural activities, members of farm households tend to engage in private commercial activities to earn a living, such as : leasing rooms, opening small beverage stalls, running small shops that serve breakfast or lunch, small groceries, fast food stalls, etc. Their regular customers are mainly students, workers, and villagers. Some-almost of them are womensell beverages along the streets around My Dinh Complex Sport Center, an area that attracts many young people from urban Hanoi or surrounding regions for entertainment, especially on weekends or holidays. The results of my survey show that the percentage of households whose wage earners engage in these commercial activities had ballooned from $16.8 \%$ in 2000 to 66.0 $\%$ in 2006. They now earn more money than ever before.

Yet, it is too early to predict a bright future for the household economies in Me Tri commune due to the following three factors: (1) Small and temporarily-built stalls and rented rooms run by peasants in Me Tri commune can only serve students, itinerant workers, or villagersmembers of the low-income class. As they cannot provide good services of high quality, they are judged to be unable to compete with those who come from other regions. These outsiders own big, beautiful, modern restaurants, cafeterias, or hotels that appeal to newcomers in middle and higher income brackets who work or live in new, modern buildings; (2) Even though $10.5 \%$ of the households in Me Tri commune rely on selling beverages on the streets near My Dinh National Complex Sport Center, doing so is actually illegal because it undermines security and obstructs public space; (3) Over a six-year period, from 2000 to 2006, the number of smallscale private businesses increased, enabling main wage earners to provide for their families from the outset in the new economic environment. This market is now saturated. The number of regular customers of small-scale businesses-typically seasonal workers and students-will necessarily decrease. Seasonal workers move to other regions after completing their jobs, while the relocation of universities and colleges to rural areas will result in a smaller number of resident student customers. As potential demand declines, the supply market in Me Tri commune may eventually exceed the needs of the market, and the inhabitants should once more be able to find other suitable jobs. Besides, $10.5 \%$ of laborers also engage in other occupations, such as motorbike drivers (xe ôm), peddlers (bán hàng rong), assistant construction workers, part-time electricians, votive paper makers, etc. About $0.8 \%$ of the labor force is said to be unemployed.

The local peasants seem to be marginalized from the modern development underway in their own hometown. I did not find any cases of peasants being officially employed in new or modern construction work. They are in a lower class than white-collar workers and medium and upperclass immigrants because of their low educational level, few work skills, or lack of industriousness, which hinders them from finding good jobs. Of 152 farm households, only 64.4 $\%$ of the main wage earners had graduated from secondary school. Only a few laborers-no more than $4.0 \%$-were estimated to have graduated from college or attended a training college. Moreover, the average age of the two main wage earners (normally a husband and a wife) in each farm household was 44 years old, an age that is not conducive to becoming acquainted with new jobs in non-agricultural sectors. In contrast, agricultural activities and foodstuff production allow even those laborers who are over 60 years old to contribute to their family's income. This is the foremost difficulty that the peasants in Me Tri commune face in the process of land use 


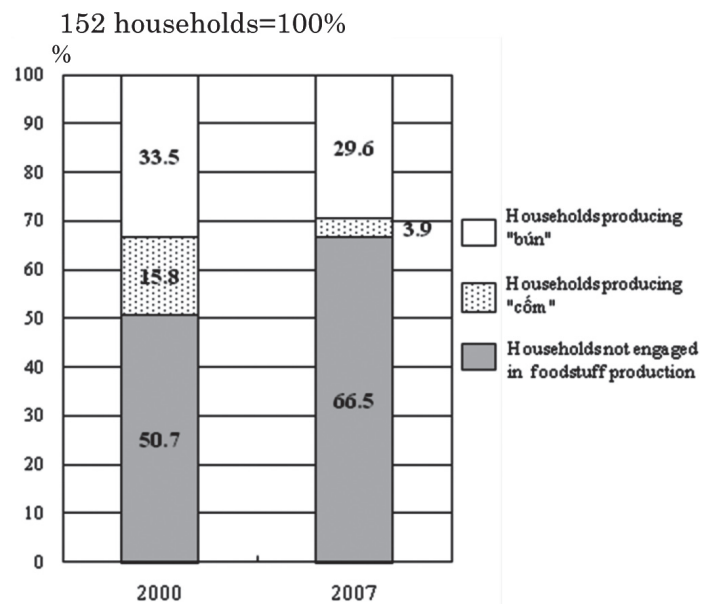

Figure 4. The percentage of households that engaged in traditional foodstuff production.

Data source : original survey data, 2007

transition and urbanization. Young and healthy peasants also find it difficult to join the industrial sector since jobs arranged for them by the state are unappealing, for example: making shoes, making clothes, etc., as they think it is hard work and pays a low salary. Better jobs, such as white-collar company employees, motorbike or auto repair, auto driver, etc., are not provided for them. They are still waiting for the state to provide them with better opportunities or for the next agricultural land conversion projects.

\section{Decline in Traditional Foodstuff Production}

Cốm (young, green sticky rice, packed in lotus leaves) and bún (white rice noodles) are both typical foodstuffs made by Me Tri commune's inhabitants. Indeed, among residents of Hanoi, bún of Phu Do village has become a well-known product, and is often consumed in and around Hanoi. The local inhabitants have an opportunity not only to preserve and develop production of their traditional foodstuffs, but to stabilize their livelihoods after agricultural land conversion through the production of côm and bún. If they succeed in maintaining their traditional foodstuff production, there are economic, social and cultural benefits : conservation of a traditional occupation and foodstuff production; creation of jobs for the peasants and other people ; and high revenues for producers thanks to the increase in foodstuff prices and urban dwellers' interest in traditional products. Based on the survey samples, however, I estimate that in reality, the number of households producing cốm and bún constituted $49.3 \%$ of the total in 2000, and decreased to $33.5 \%$ in 2007 (Figure 4 shows more details on this trend).

In more detail, till 2007, the number of households producing bún in Phu Do village decreased by $3.9 \%$, while that of households producing cốm in Me Tri Ha and Me Tri Thuong villages decreased by $11.9 \%$ in spite of high income during the producing seasons. The following factors shed light on the problems :

Firstly, foodstuffs are labor-intensive, requiring the efforts of at least two laborers for an entire day (in the producing seasons- $v u$ chiêm-the first harvest from March to May; and the second, $v u$ mùa, from July to October), and adequate food resources : rice of high enough quality for producing bún and special baby paddy seed for producing cốm. Because the remaining cultivated land area in Me Tri commune has not been able to meet the demand, peasants in Me Tri Ha 
Table 1. How households spent compensation money

\begin{tabular}{l|r}
\hline \multicolumn{1}{c|}{ Usage of compensation money } & Percentage of households (\%) \\
\hline Built 1.5-to-3-floor house & 59.4 \\
Repaired house : repaired roofs, rebuilt bathroom or restroom, painted walls & 7.9 \\
Bought motorbikes, cell phones & 58.4 \\
Purchased furniture : refrigerator, television, washing machine, etc. & 59.4 \\
Invested in private business supplies : built rooms for rent, bought tables, chairs or other things & 47.5 \\
necessary for small beverage/food stalls ; bought machines to make cốm, etc. & 13.9 \\
Other purposes : paid for medical care, transferred money to sons or daughters, repaid loans & \\
\hline
\end{tabular}

and Me Tri Thuong villages should contact peasants in surrounding areas such as Soc Son, or Dong Anh (suburban districts of Hanoi, farther than 20-30 km from Me Tri commune) to collect baby rice every day in côm-producing seasons. Distance is the main factor in dampening enthusiasm for preserving traditional foodstuff production.

Secondly, many households prefer to expand their living houses for commercial purposes or for their own living purposes. As a result, they reduce available land for foodstuff production, and in many cases, retain no land for traditional foodstuff production at all.

Last but not least, the peasants in Me Tri Ha and Me Tri Thuong villages can't maintain cốm production throughout the year, but only in the cốm seasons. Main wage earners have to engage in other jobs in the slack seasons. In some cases, households earn 3-4 million VND/month or even more in the cốm seasons, but they earn very little during the rest of the year (some could not be assured their income would rise above the poverty line of Hanoi city of 270,000 VND/ month). Obviously, they hope to get more stable jobs to feed their families throughout the year. In other cases, the peasants told us that they are not involved in production of foodstuffs because they desire to find jobs that do not involve the drudgery that they endured in the past.

\section{Usage of Compensation Money and Future Risks}

After receiving hundreds of million VND in exchange for the return of agricultural land, far more than they had ever earned before, the peasants in Me Tri commune found that they had suddenly become wealthy. Once they attained access to things that they could not afford before, they were eager to do so, sometimes without waiting for savings to accumulate, or for better occupational opportunities. They spent a lot of money on building big houses, purchasing expensive motorbikes, cell phones, or furniture, items that symbolize an urban lifestyle.

The data in Table 1 indicates that about $60.0 \%$ of interviewed households preferred spending their compensation money on building houses or buying expensive furniture. $47.5 \%$ of them invested in new rooms for rent or beverage/food stalls. On the other hand, the money used for vocational purposes was comparatively low.

Households spent an average of 213 million VND for new homes. This is nearly 9.5 times more than the income a household with two main wage earners can normally earn in a year, and twofold more than the average amount of money they were compensated. In contrast, the money they spent on setting up small private businesses was 40 million VND, which comprises only $18.7 \%$ of the total money they spent for new homes. There was no cooperation or shared holdings among the compensated peasants for initiating business projects and no occupational support organizations to be found.

In terms of social activities, some interviewees said that since the villagers had become richer from the compensation money, they held larger-scale ceremonies (celebration for construction 
Table 2. Years of saving required to repay loans

\begin{tabular}{c|c|c}
\hline Number of years required to save money to repay loans & Number of households & Percentage of total households (\%) \\
\hline 0 & 68 & 44.8 \\
$1-3$ & 28 & 18.4 \\
$3-5$ & 9 & 5.9 \\
$5-10$ & 14 & 9.2 \\
$>10$ & 19 & 12.5 \\
No ability to repay loan & 14 & 9.2 \\
\hline
\end{tabular}

of a new house, a wedding party, death anniversary, etc), to which more guests were invited. Guests in turn were expected to give more money (at least 3-5 times previous amounts) as gifts.

Actually, the total money the peasants received was not sufficient for purchasing these items, which cost about 2.5 times more than the amount they received. This issue raises a new question: where did the rest of the money come from? According to the household surveys, the rest of the money comes partly from savings, but mainly from incurring debt. Many peasants borrowed money from their relatives, and a few from commercial banks. Remarkably, their average current income, approximately 3,508,000 VND/month/household or 938,000 VND/ month/labor was not enough to repay their debts in a short time. The formula below, in simplified form, is used to evaluate the ability of peasants to repay loans, based on the hypothesis that the interest rate for paying off debt equals zero, and that the peasants gradually repay year by year :

$$
\mathbf{T}=\mathbf{d} /(\mathbf{a}-\mathbf{b})
$$

Where $\quad T$ : defines the number of years required for a household to repay loan

$\mathrm{d}$ : defines total loans (VND)

a : refers to revenues of each farm household (VND per year)

$\mathrm{b}$ : refers to the expenditure per year necessary to satisfy minimum living expenses such as food, electricity costs, education fees, telephone bills, expenses for weddings or funerals (VND per year).

The result is shown in Table 2.

Even supposing that the peasants spent little money on living expenses, and owed money with no interest, it is still difficult for them to repay loans. Among 152 survey samples, 84 households, or $55.2 \%$ of the total, are unquestionably in debt; $9.2 \%$ should save money constantly for at least five to ten years to repay their loans. Another $12.5 \%$ cannot repay all the money before the tenth year without assistance, while $9.2 \%$ can only repay their loans by means of transferring a part of their residential land. In fact, the fastest way for peasants to repay loans is to wait until they receive compensation for projects that require the state to convert the rest of their agricultural land. In other words, to repay their debts, some of them have to transfer their real estate, either partially or entirely, at rates that are skyrocketing in price during the transition in land use. In this case, they cannot retain enough land to support their sons when the latter get married, as is the traditional custom, or households must move to other regions to purchase cheaper houses to save money. In either case, it is apparent that the peasants depend heavily on exogenous conditions rather than on subjective abilities for their livelihoods. 


\section{Conclusion}

The increasing insufficiency of available land for urban development as well as high population density in the inner region has inspired need of urbanization at a rapid rate of Hanoi within these fifteen years. With its strategic location on the urbanizing trend of Hanoi, Me Tri commune is the representative case for the rapid conversion from agricultural land into nonagricultural land during the urbanization.

It was only six years from 2000 to 2006 that witnessed the decline of agricultural land in Me Tri commune from $60 \%$ to $36 \%$ in land use structure, and the parallel process of emerging several essential buildings for administration, sport, and residence. From a rural area, Me Tri commune has been transited into a quasi-urban area, which results in a labor transition from an agricultural to a non-agricultural economy, as well as a transformation in lifestyle from rural to urban of the peasants.

By adopting the bottom-up approach in a small scale of Me Tri commune, this research can evidently point out three burdens on the peasants in this commune during the urbanization at a rapid rate as results of the process of agricultural land conversion. The three burdens are labor transition, decline in traditional foodstuff production, and future risks of the peasants in related to the usage of compensation money. Through the research, it is recognized that the first and foremost problem challenging the peasants in agricultural land conversion must be the labor transition. From the outside, it is easy to conclude that as peasants in Me Tri commune can cash in on urbanization by leasing rooms or opening small restaurants to serve temporary residents, they are under good conditions. Their living standards have been improved through the land conversion. It is only by seeing the situation from the inside to understand that the peasants in Me Tri commune really feel uneasy when they are expected suddenly to enter a competitive market. Because of being ill-equipped to adapt to the transformation, peasants in Me Tri commune find it difficult to adjust to the new composition of their hometown, which now requires a solid educational background, work skills or ability to provide competitive services. Besides, under the unstable conditions, they feel confuse about how to invest compensation money effectively, as well as how to stabilize their life in future. In parallel with the incursion of urban dwellers, some low-income residents who have not been able to adapt to the new urban environment are planning to sell their residential land and move to the surrounding areas in the near future.

It is unfortunate that regardless of recognizing that the foodstuff industry is a good means to eliminate their current difficulties in the new economic environment, many inhabitants in $\mathrm{Me}$ Tri Thuong and Me Tri Ha villages and some in Phu Do village privately feel unable to engage in the food industry without outside support. The burden on them does not reflect only local problems, however, as a similar situation has also arisen in other urban fringes or rural areas. As a result, the threat to food product security and preservation of traditional culture is exacerbated, impacting the larger community.

Actually, the unpredictable risks that these compensated peasants face do not differ from those of land sellers in the free market, or landed farmers in other countries. The only difference between them is that while the latter decide themselves an appropriate price at which to sell their land and take responsibility for their decisions, the former have to give up their land, 
sometimes without a satisfactory compensation price or the chance to prepare beforehand to look for new jobs. Peasants place responsibility on the state and planners for risk of their unemployment and unstable livelihoods after agricultural land conversion. Also, they wait passively for support from the state. In the author's opinion, these urgent problems result from the methods of agricultural land recovery for urban development. By conducting agricultural land recovery for urbanization, Vietnam could avoid uncertainties in timing and procedures for acquiring land. However, Vietnam, as well as other countries, cannot avoid problems when intervening in the interactive bond between peasants and agricultural land.

In the near future, agricultural land in Me Tri commune will be converted into various zones: a park, a museum, urban residential zones, and a sports zone, according to a blueprint for $\mathrm{Tu}$ Liem district. Also, in 2008, a new decision was made to expand Hanoi 3.6 times in area, creating an urgent need for transition in agricultural land use. In all probability, the result will be severe problems for the surrounding suburbs or rural areas, as has happened in Me Tri commune.

Based on this research, the author has devised several rational revisions in the implementation of recovering agricultural land and compensation to ameliorate the difficulties facing peasants. My suggestions are as follows : In terms of living and employment support for the peasants : (1) Educate the peasants on possible emerging risks during rapid urbanization and on careful usage of compensation money. (2) If possible, form a cooperatively-run commercial center for producing foodstuffs under the auspices of a suitable organization or through cooperation of displaced peasants to ensure preservation of traditional occupations as well as to bring stable profits to peasants; In terms of methods of compensation, payment should be made in the form of real estate (land, rooms, or apartments) in the new urban zone, instead of cash, as is the usual method. This method of payment would help peasants attain stable benefit, and partly reduces unfairness in compensation price when agricultural land is recovered at different times; Some suggestions for methods of agricultural land recovery are: (1) Conduct smooth negotiations between planners and local representatives of peasant groups with the support of third-party government coordinators ; (2) Delineate responsibilities for planners in arranging for new jobs for peasants; extend the period of time between announcement of agricultural land recovery and its implementation.

\section{Acknowledgements}

I had opportunity to present this research to many scholars and students in the 2008 annual meeting of the Human Geographical Society of Japan, on 10 November. My gratitude firstly goes to Prof. PHAM Van $\mathrm{Cu}$ and other professors from the CHATsea Project (Challenges of agrarian transition in Southeast Asia) for their valuable support in providing me with scientific knowledge and financing for my study. In fact, this topic is quite sensitive, I could not have conducted this research without the help and kind $\mathrm{co}^{-}$operation of local governmental officials as well as many residents in the Me Tri commune. I am sincerely grateful to them. I would also like to express my appreciation to Prof. NOMA Haruo and Prof. TAKAHASHI Seiichi for their scientific advices, and warm support throughout the time I was writing this paper. In terms of my English writing skills, I would like to express my appreciation to my English teacher, Jenine HEATON, who kindly gave of her time to correct my English and induce confidence in my English academic writing. I also want to thank Dr. TSUTSUI Kazunobu, and Ass. Prof TSUTSUI Yukino, Prof. NGUYEN Cao Huan, Ass. Prof. NGUYEN Thi Hai, Dr. TRAN Anh Tuan. They 
were always there to provide me with warmhearted encouragement and helpful comments on the paper.

\section{Notes}

1. The national strategy was made in order to "avoid the problems associated with large urban agglomerations," and "to eliminate as much of the private sector as possible" (Forbes 1996).

2. Urban population is defined as the number of people living in urban areas.

3. Accordingly, H. D. Evers and R. Korff (Evers and Korff 2003) have used these terms to label the phenomena in Southeast Asian countries to indicate the peculiarity in pattern of urbanization, of which the main force is not industrialization or economic development. It may exclude Thailand and Indonesia, of which "urbanization is at present closely linked with industrialization" (Evers and Korff 2003).

4. It is defined as the rate of transition of the urban population (the number of people living in urban areas) over a given period of time.

5. Although the percentage of urban dwellers in the total population of Vietnam increased during the five years 19982003 from $23 \%$ to $26 \%$, it was just equal to that of Laos in 2003 ; while the urban population ratio of Thailand, Indonesia and the Philippines increased much more-from $31 \%-32 \%, 39 \%-43 \%$ and $57 \%-61 \%$ in the same period, respectively. That is why the World Bank classified Vietnam as a country at a low level of urbanization, on par with Cambodia and Laos (United Nations Population Division 2007; World Bank 2003).

6. In this paper, the author prefers using the term "peasant," which is "on family farms (farming households) which function as relatively corporate units of production, consumption and re-production." Most of the peasants in Vietnam (at least in the northern and central Vietnam) work in sparse and small land parcels, normally for self-sufficient consumption (Johnston et al. 2000, 575-576).

7. In terms of administrative units, Hanoi, as a city under the central government, is composed of an inner region and an outer region. The inner region including nine urban districts $\left(180.7 \mathrm{~km}^{2}\right.$ in area, with 1.9 million people), is considered an urban area, where population concentration and economic agglomerations are at a high degree; while the outer region, consisting of five rural districts $\left(735.8 \mathrm{~km}^{2}\right.$ in area, with 1.2 million people), is less urbanized and developed than the inner region. Smaller administrative units of urban districts and rural districts are ward, and commune, respectively (General Statistic Office 2006, 9-50).

8. The index is described as the number of people living in the inner regions (wards) per the total population of the city.

9. To refer to the process of compulsorily recovering land use right from an organization or the people's committee of a commune, ward or township for administration in the case of Vietnam, the term of "land recovery" is used (Vietnam National Assembly, Land Law 2003, Ministry of Planning and Investment, March 2004). While in other cases (Japan, Korea, Philippines, etc) the term of "land acquisition" is better for referring to the process in which the state acquires land (ownership right) from landowners.

10. VND, or đông. 1yen $=132.05 \mathrm{VND}$ (July, 2007).

11. According to the land law of Hanoi, the quality of soil is categorized in degrees ranging from level 1 to level 7 (Hanoi People's Committee 1998).

12. In other words, $\mathrm{K}$ also defines the ratio between the price determined by the real estate market and the price determined by the Provincial People's Committee (Ministry of Finance 1998).

13. sào is an area unit of agricultural land measurement in Vietnam. 1 sào $=360 \mathrm{~m}^{2}$ in the northern part.

\section{References}

Asian Development Bank. (2007) Making Markets Work Better for the Poor Project. http : //market4poor. org (last accessed August 18, 2010). (In Vietnamese and English)

Dwyer, D. (1990) Urbanization. In South East Asian development: Geographical perspectives, ed. D. Dwyer, 278-308. United Kingdom : Longman Group UK Ltd.

Evers, H. D., and Korff, R. (2003) Southeast Asian urbanism. Münster : Lit Verlag.

Forbes, D. (1996) Asian metropolis. Melbourne: Oxford University Press.

General Statistics Office. (2006) Socio-economic statistical data of 671 districts, towns and cities under the authority of provinces in Vietnam. Hanoi: Statistical Publishing House. (In Vietnamese and English)

General Statistical Office. (2010) Socio-economic statistical data http://www. gso. gov. vn (last accessed 18 August, 2010). (In Vietnamese)

Hanoi People's Committee. (1998a) Decision 20/1998/QD-UB [Quyet dinh 20/1998/QD-UB] (In Vietnamese).

Hanoi People's Committee. (1998b) Decision 33/1998/QD-UB [Quyet dinh 33/1998/QD-UB] (In Vietnamese).

Hanoi People's Committee. (2003) Decision 99/2003/QD-UB [Quyet dinh 99/2003/QD-UB] (In Vietnamese). 
Hanoi People's Committee. (2004) Decision 199/2004/QD-UB [Quyet dinh 199/2004/QD-UB] (In Vietnamese). Hanoi People's Committee, (2005) Decision 26/2005/QD-UB [Quyet dinh 26/2006/QD-UB] (In Vietnamese).

Ho, D. D., and Shibayama, M. (2009) Studies on Hanoi urban transition in the late 20th century based on GIS/RS. Southeast Asian Studies 46 : 532-546.

Johnston, R. J. et al. (2000) The dictionary of human geography. Oxford : Blackwell Publishing.

Jonathan, R. (2003) Southeast Asia: The human landscape of modernisation and development. London : Routledge.

Leaf, M. (2002) A tale of two villages: Globalization and peri-urban change in China and Vietnam. Cities 19:23-31.

Limi, A. (2005) Urbanization and development of infrastructure in the East Asian region. JBICI Review 10:88-109.

Ministry of Agriculture and Rural Development. (2007) General report. Paper submitted to the conference on "Land Recovery from the Peasants, Present Situation and Solutions" [Thu hoi dat cua nong dan, thuc trang va giai phap]. Hanoi. July 7, 2007. http : //www. khuyennongvn. gov. vn (last accessed August 18, 2010). (In Vietnamese)

Ministry of Finance. (1998) Circular 145/1998/TT-BCT [Thong tu 145/1998/TT-BCT] (In Vietnamese).

National Economic Research Institute of Vietnam. (2006) Agricultural land conversion for industrial and commercial use, competing interests for the poor. Market and Development Bulletin $8: 1$.

Nguyen, T. (1974) Urbanization processes in North Vietnam. Soviet Geography 15 : 352-357.

Nguyen, V. Q. et al. (2005) The impact of urbanization on agriculture in Hanoi (Results of interviews with district and municipality officials). The EU 5th Framework INCO2 funded research project (SEARSYN), Hanoi.

Noma, H. (1999) Hanoi as a rural-urban interaction model : Urbanization and rural transformation after Doi Moi [Toshi-noson kankei moderu toshite no Hanoi-toshika to Doimoi iko no noson henka]. In Studies on metropolitan area: Multi-approaches [Daitoshiken Kenkyu-Tayou na Apurochi], ed. K. Narita, Tokyo: Taimeido. (In Japanese)

People's Committee of Me Tri commune (Department of Resources and Environment). (2000-2006) Land use of Me Tri Commune [Hien trang su dung dat xa Me Tri] (In Vietnamese).

People's Committee of Tu Liem Suburban District. (2000-2006) Statistics year book [Nien giam thong ke] (In Vietnamese).

Pham, M. H., and Yamaguchi, Y. (2008) Characterizing the urban growth of Hanoi, Nagoya, and Shanghai City using remote sensing and spatial metrics. Boston : International Geosciences and Remote Sensing Symposium's Proceedings : 9-12.

Thrift, N., and Forbes, D. (1986) The price of war: Urbanization in Vietnam 1954-85. London : Allen \& Unwin.

Vietnam Government. (1995) Resolution 69/CP [Nghi quyet 69/CP] (In Vietnamese).

Vietnam Government. (1996) Resolution 74/CP [Nghi quyet 74/CP] (In Vietnamese).

Vietnam Government. (2001) Decree 72/2001/ND-CP [Nghi dinh 72/2001/ND-CP] (In Vietnamese).

Vietnam Government. (2003) Resolution 132/2003 [Nghi quyet 132/2003] (In Vietnamese).

United Nations Population Division. (2007) World urbanization prospects: The 2007 revision population database. http : //esa. un. org (last accessed August 18, 2010).

Vu, H. P. (2006) Impacts of urbanization in a peri-urban area of Hanoi: The voice of affected people. Vietnam Social Sciences $5: 51-60$.

World Bank. (2003) Urban poverty in East Asia : A review of Indonesia, the Philippines and Vietnam. Working paper.

\title{
Conversion of Agricultural Land and its Impacton Peasants in Hanoi Suburbs During Rapid Urbanization : A case study of Me Tri Commune
}

\author{
NGUYEN Thi Ha Thanh, \\ Graduate Student, Global COE-Research Assistant, Kansai University
}

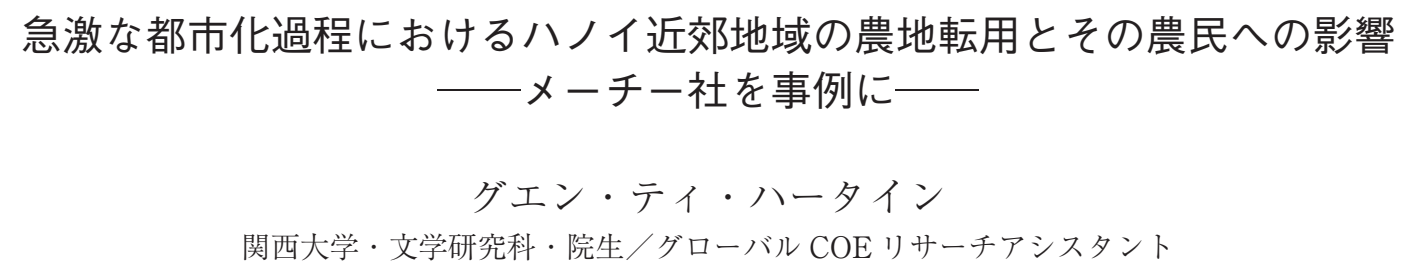

近年約15年の間に, ベトナムの首都で国内第二の都市であるハノイでは急激に都市化が進み, 近郊農 
村では多くの農地が工業用地，商業用地，住宅に転用された。本研究の目的はハノイ近郊における農地 転用とその農民への影響を明らかにすることであり，社（行政村）という小地域での世帯インタビュー 調査結果から帰納的にアプローチ寸る。本稿は 3 つの部分で構成されている。まずハノイ市の急速な都 市化と農地収用にともなう諸政策，とりわけ農地転用に伴う補償制度について概観する。そのうえで, 事例地域であるメーチー社における2000年から2007年にかけての農地転用, 農地収用, 農地補償の実態 を明らかにする。本研究を通じて, メーチー社では農村地域から都市化された地域へと急速に変化し, その結果，農民の生活様式や職業までもが変容してきたことが明らかになった。その上で，農地転用の 農民への影響を検討し, 就業構造の変化, 伝統的な食品加工業の低迷, 農地保障金の利用実態と将来の リスクといった問題を抽出した。

キーワード : 都市化, 農地転用, 農民, ハノイ, ベトナム 